\title{
PENGARUH EKSTRAK BUAH DELIMA MERAH TERHADAP KADAR SOD PADA KULTUR HUVECs YANG DIPAPAR PLASMA PREEKLAMPSI
}

\author{
Januarsih ${ }^{1}$, Tut Barkinah ${ }^{2}$ \\ 1,2 Dosen di Poltekkes Kemenkes Banjarmasin, Jl. M. Cokrokusumo No. 1A Banjarbaru \\ Email: januarsih.januarsih@gmail.com \\ Telp: 082234273459, 08125030126
}

\begin{abstract}
ABSTRAK
Preeklampsi merupakan sindroma yang berkaitan dengan adanya gejala vasospasme, peningkatan terhadap resistensi pembuluh darah perifer dan juga penurunan perfusi organ. Salah satu teori etiologi preeklampsi yang dianut saat ini mengatakan adanya ketidakseimbangan antara produksi radikal bebas dan sistem pertahanan antioksidan yang menyebabkan timbulnya stres oksidatif, ditandai dengan adanya penurunan aktivitas antioksidan disertai dengan adanya peningkatan kadar lipid peroksida (oksidan / radikal bebas). Keadaan ini tentu saja menimbulkan terganggunya fungsi endotel bahkan rusaknya seluruh struktur sel endotel yang disebut sebagai disfungsi endotel. Keadaan stres oksidatif bisa dikendalikan dengan pemberian anti oksidan yang terbagi dalam antioksidan enzimatis dan non enzimatis. Antioksidan enzimatis terdiri dari superoksida dismutase (SOD), glutation peroksidase dan katalase. Buah delima mengandung fitokimia dan kaya akan senyawa yang berfungsi sebagai antioksidan yaitu polifenol, tanin dan anthocyanin. Tujuan penelitian ini adalah untuk mengetahui efek pemberian ekstrak buah delima merah merah (Punica granatum) terhadap kadar SOD pada kultur HUVECs yang dipapar plasma preeklampsi.

Rancangan percobaan berupa rancangan acak lengkap dengan 5 kelompok perlakuan yaitu, Kelompok I : Kontrol negatif (K-) HUVECs + plasma kehamilan normal 2\%, Kelompok II : Kontrol positif $(\mathrm{K}+)$ HUVECs + plasma preeklampsi 2\%, Kelompok III : Perlakuan 1 (P1) HUVECs + plasma preeklampsi $2 \%$ + ekstrak buah delima merah 14 ppm, kelompok IV : Perlakuan 2 (P2) HUVECs + plasma preeklampsi $2 \%$ + ekstrak buah delima merah 28 ppm dan Kelompok V : Perlakuan 3 (P3) HUVECs + plasma preeklampsi $2 \%$ + ekstrak buah delima merah 56 ppm.

Berdasarkan pada hasil uji LSD $5 \%$ menunjukkan bahwa kelompok kontrol negatif (K-) memiliki rata-rata kadar SOD berbeda nyata dengan kelompok kontrol positif $\left(K_{+}\right)(p=<0,05)$. Peningkatan kadar SOD secara signifikan ditunjukkan oleh pemberian ekstrak buah delima merah pada konsentrasi 56 ppm. Bahkan, pemberian ekstrak buah delima merah konsentrasi 56 ppm mampu meningkatkan kadar SOD hingga lebih tinggi daripada kelompok kontrol negatif $(p=<0,05)$, sedangkan pemberian ekstrak buah delima merah pada dengan konsentrasi 14 ppm dan 28 ppm, belum mampu meningkatkan kadar SOD secara signifikan $(p=>0,05)$.

Sehingga dapat disimpulkan, bahwa pemberian ekstrak buah delima merah (Punica granatum) terbukti dapat meningkatkan kadar SOD pada kultur HUVECs yang dipapar plasma preeklampsi.
\end{abstract}

Kata Kunci : Delima Merah, Antioksidan, SOD dan Preeklampsi 


\section{PENDAHULUAN}

Angka kejadian preeklampsi diperkirakan sekitar antara 5 - 10\% dari seluruh kehamilan di dunia (WHO, 2002; Habli \& Sibai, 2008; Gupta et al, 2009). Preeklampsi juga menyumbang sekitar $16 \%$ dari seluruh kematian ibu di negara maju (Habli \& Sibai, 2008). Salah satu teori etiologi preeklampsi yang dianut saat ini mengatakan adanya ketidakseimbangan antara produksi radikal bebas dan sistem pertahanan antioksidan yang menyebabkan timbulnya stres oksidatif (Roberts \& Hubel, 2004).

Keadaan stres oksidatif bisa dikendalikan dengan anti oksidan. Antioksidan itu sendiri, ada yang memang sudah terdapat di dalam tubuh (endogen) dan ada yang diperoleh dari luar tubuh (eksogen). Secara umum, antioksidan dibedakan menjadi 2 kelompok yaitu: antioksidan enzimatis / antioksidan primer / antioksidan pencegah dan antioksidan non enzimatis terdiri dari superoksida dismutase (SOD), glutation peroksidase (GSHPx) dan katalase (CAT) (EI Bahr, 2013).

Buah delima merah memiliki senyawasenyawa yang berharga pada berbagai bagian buah, serta efek yang fungsional dan medis seperti antioksidan, antikanker dan anti-aterosklerosis yang telah dibuktikan (Mousavinejad et al., 2009). Buah delima merah mengandung fitokimia yang kaya akan senyawa yang berfungsi sebagai antioksidan yaitu polifenol, tanin dan antosianin (Kholifa, 2010).

\section{METODE}

Penelitian ini adalah true experimental (eksperimental sesungguhnya) dengan pendekatan post test only control group design. Dalam penelitian ini perlakuan atau intervensi peneliti yaitu HUVECs yang dipapar plasma penderita preeklampsi dilanjutkan dengan pemberian ekstrak buah delima merah berbagai dosis terhadap kultur tersebut. Sedangkan fenomena yang terjadi akibat adanya perlakuan atau intervensi dari peneliti hanya diamati setelah perlakuan atau intervensi tersebut diberikan dalam penelitian ini adalah kadar SOD pada kultur HUVECs. Rancangan percobaan berupa rancangan acak lengkap dengan 5 kelompok, yaitu 2 kelompok sebagai kontrol, Kelompok Kontrol Negatif (K-) dan Kelompok Kontrol Positif (K+) serta 3 Kelompok Perlakuan (P1, P2, P3).

Kelompok Kontrol Negatif (K-) adalah kultur HUVECs dipapar plasma kehamilan normal 2\%. Kelompok Kontrol Positif $\left(K_{+}\right)$ yaitu kultur HUVECs dipapar plasma preeklampsi 2\%. Kelompok Perlakuan 1 (P1) adalah kultur HUVECs dipapar plasma preeklampsi $2 \%$ dan ekstrak buah delima merah dengan dosis 14 ppm. Kelompok Perlakuan 2 (P2) yaitu kultur HUVECs dipapar plasma preeklampsi $2 \%$ dan ekstrak buah delima merah dengan dosis 28 ppm. Kelompok Perlakuan 3 (P3) ialah kultur HUVECs dipapar plasma preeklampsi $2 \%$ dan ekstrak buah delima merah dengan dosis 56 ppm. Masing - masing dari semua perlakuan diinkubasi selama 24 jam. 
Pengukuran kadar Superoksida Dismutase (SOD) memakai teknik elisa. Menggunakan kit, yang diproduksi oleh MyBiosource dengan nomor katalog MBS727133. Sebelum digunakan, semua komponen kit di tempatkan pada ruang dengan suhu kamar $\left(20-25^{\circ} \mathrm{C}\right)$. Membuat larutan untuk $1.000 \mathrm{~mL}$ Wash Solution dengan cara melarutkan $10 \mathrm{~mL}$ konsentrat Wash Solution $(100 \times)$ dengan $990 \mathrm{ml}$ deionisasi.

\section{HASIL}

Tabel 1 Pengujian Kadar SOD dengan ANOVA dan LSD $5 \%$

\begin{tabular}{ccc}
\hline Perlakuan & Mean \pm SD & p-value \\
\hline K- & $11.991 \pm 1.92^{\mathrm{b}}$ & \\
$\mathrm{K}_{+}$ & $5.290 \pm 0.538^{\mathrm{a}}$ & \\
$14 \mathrm{ppm}$ & $4.851 \pm 0.870^{\mathrm{a}}$ & 0.000 \\
$28 \mathrm{ppm}$ & $6.692 \pm 1.666^{\mathrm{a}}$ & \\
$56 \mathrm{ppm}$ & $23.44 \pm 1.981^{\mathrm{c}}$ & \\
\hline
\end{tabular}

Keterangan: Pada rata-rata $\pm \mathrm{sd}$ jika memuat huruf yang berbeda berarti ada perbedaan yang bermakna $(p<0.05)$ dan jika memuat huruf yang sama berarti tidak ada perbedaan yang bermakna $(p>0.05)$.

Pada tabel 1. Telah ditunjukkan bahwa bberdasarkan hasil Uji Anova dengan menggunakan LSD 5\%, perlakuan ekstrak buah delima merah pada dosis 14 ppm dan 28 ppm belum mampu mencegah penurunan kadar SOD pada kultur HUVECs, sedangkan perlakuan ekstrak buah delima merah pada dosis 56 ppm sudah mampu mencegah penurunan kadar SOD pada kultur HUVECs secara signifikan, bahkkan mampu meningkatkan kadar SOD hingga lebih tinggi daripada kultur HUVECs dengan plasma hamil normal. Hasil penelitian ini menunjukkan bahwa ekstrak buah delima merah memang mempunyai aktivitas antioksidan, sehingga mampu mencegah penurunan kadar SOD pada sel endotel akibat adanya radikal bebas dari plasma penderita preeklampsi $2 \%$.

Pada perbandingan semua level kelompok perlakuan, perbandingan antara konsentrasi 14 ppm dengan 28 ppm didapatkan p-value lebih dari 0,05 . Hal ini menunjukkan bahwa pemberian ekstrak buah delima merah konsentrasi 14 ppm dan 28 ppm memberikan pengaruh yang sama terhadap kadar SOD. Rata-rata kadar SOD kelompok kontrol dan perlakuan secara lengkap ditunjukkan dalam histogram berikut:

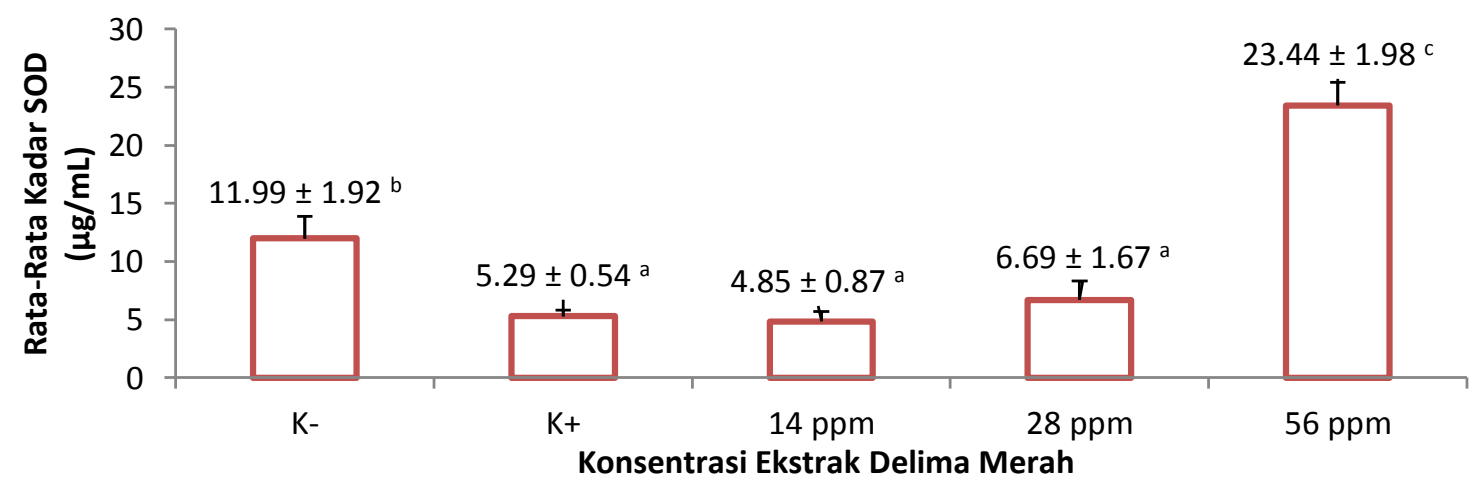

Gambar 1. Histogram Perubahan Kadar SOD.Pemberian ekstrak buah delima merah dengan konsentrasi 14 ppm dan 28 ppm belum mampu meningkatkan kadar SOD secara signifikan, sedangkan pada kelompok perlakuan 56 ppm mampu meningkatkan kadar SOD secara signifikan 
Pada Gambar 1 telah ditunjukkan histogram dari rata-rata kadar SOD kelompok kontrol dan perlakuan. Tampak rata-rata kadar SOD meningkat pada kelompok perlakuan pemberian ekstrak buah delima merah seiring dengan peningkatan konsentrasi ekstrak buah delima merah yang telah diberikan. Dimulai dari kelompok kontrol positif, berturut-turut terjadi peningkatan ratarata kadar SOD hingga titik tertinggi pada kelompok perlakuan pemberian ekstrak buah delima merah dengan konsentrasi 56 ppm.

Peningkatan ROS akan meningkatkan juga pemakaian enzim antioksidan intraseluler. Hal ini dapat menurunkan kadar dari enzim SOD yang akan meningkatkan akumulasi hidrogen peroksida di dalam sel yang menyebabkan inaktivasi SOD. Hal ini terjadi dikarenakan adanya kompensasi dari enzim antioksidan intraseluler untuk mengatasi adanya peningkatan stres oksidatif yang terjadi di dalam sel (Fukai \& Ushio Fukai, 2003). Adanya korelasi positif antara keparahan preeklampsi dan tingkat stres oksidatif yang menguatkan data bahwa ROS terlibat dalam patofisiologi preeklampsi sehingga menurunkan kadar SOD (Rodrigo et al., 2009).

Selain itu, pemberian ekstrak buah delima merah dapat meningkatkan kadar SOD sesuai dengan teori yang menyatakan bahwa pada keadaan patologik diantaranya akibat terbentuknya radikal bebas dalam jumlah berlebihan, enzim-enzim yang berfungsi sebagai antioksidan endogen dapat menurun kadarnya. Oleh karena itu, jika terjadi peningkatan radikal bebas dalam tubuh, diperlukan antioksidan eksogen untuk mengeliminir dan menetralisir efek radikal bebas (Astuti et al., 2008).

Ekstrak buah delima merah mampu meningkatkan kadar SOD dikarenakan pada buah delima merah kaya akan antioksidan. Buah delima merah (sekitar $50 \%$ dari total berat delima) terdiri dari $80 \%$ jus dan $20 \%$ biji. Pada jusnya itu sendiri terdapat $85 \%$ air, $10 \%$ gula dan $1,5 \%$ pectin, asam askorbat serta polifenol flavonoid. (de Nigris et al., 2006). Fawole et al., (2011) meyampaikan, kandungan antosianin di dalam buah delima merah mencapai 16,5 - 26,9 per 100 gram jusnya. Antosianinlah yang bertanggungjawab atas pewarnaan pada buah delima merah.

Warna diberikan oleh antosianin berdasarkan susunan ikatan rangkap terkonjugasinya yang panjang, sehingga mampu menyerap cahaya pada rentang cahaya tampak. Sistem ikatan rangkap terkonjugasi ini juga yang mampu menjadikan antosianin sebagai antioksidan dengan mekanisme penangkapan radikal. Radikal bebas adalah atom atau senyawa yang mengandung satu atau lebih elektron yang tidak berpasangan. Senyawa paling berbahaya dalam radikal bebas adalah hidroksil $(\mathrm{OH})$ sebab memiliki reaktivitas paling tinggi. Molekul tersebut sangat reaktif dalam mencari pasangan elektronnya. Jika sudah terbentuk dalam tubuh, maka akan terjadi reaksi berantai dan menghasilkan 
radikal bebas baru yang akhirnya membentuk suatu radikal bebas dalam jumlah yang banyak (Harborne, 2005).

Antioksidan merupakan suatu zat atau senyawa yang mampu memperlambat atau mencegah proses oksidasi, melindungi sistem biologis, melawan efek potensial dari proses atau reaksi yang menyebabkan oksidasi berlebihan. Tubuh memiliki sistem pertahanan radikal bebas berupa antioksidan enzimatik dan non enzimatik. Sistem antioksidan enzimatik disusun oleh superoksida dismutase, katalase dan peroksidase yang tergabung dalam mekanisme pertahanan terhadap ROS (El Bahr., 2013).

Superoksida dismutase merupakan antioksidan enzimatik yang berfungsi sebagai pertahanan garis depan melawan ROS dalam sel hidup. Jika dibiarkan, superoksida dapat mengkonversi ke radikal hidroksil yang sangat merusak dan dapat menyebabkan perubahan pada DNA, kerusakan protein dan lipid. Enzim superoksida dismutase (SOD) mengkatalisis dismutasi radikal anion superoksida $\left(\mathrm{O}^{-}\right)$ menjadi $\mathrm{H} 2 \mathrm{O} 2$ dan $\mathrm{O} 2$ (Perry et al., 2010, Fukai \& Ushio-Fukai, 2011). Dalam mitokondria, SOD berfungsi mengatur scavenging dari anion superoksida $\left(\mathrm{O}^{-}\right)$, memproduksi $\mathrm{H} 2 \mathrm{O} 2$, penghambatan produksi ONOO dengan melindungi NO dalam matriks mitokondria (SOD2) dan dalam ruang antar membran (SOD1) (Fukai \& Ushio-Fukai, 2011).

Dalam fungsi vaskuler, SOD1 memainkan peran penting dalam fungsi endotel dengan melindungi pelepasan NO dari endotelium. Superoksida dismutase 2 (SOD2) memainkan peran penting dalam mengatur fungsi endotel. Defisisensi SOD2 bertanggung jawab untuk disfungsi endotel dengan meningkatkan $\mathrm{O}^{-}$dan menyebabkan kerusakan kronis mitokondria dalam apoE. Superoksida dismutase 3 (SOD3) memainkan peran penting dalam mencegah kerusakan NO yang dilepaskan dari endotelium (Fukai \& Ushio-Fukai, 2011).

Dari banyak teori yang telah dikemukakan sebagai penyebab terjadinya Preeklampsi, di antaranya adalah (1) teori iskemia plasenta, radikal bebas, dan disfungsi endotel, (2) teori intoleransi imunologik antara ibu dan janin, (3) teori kelainan pada vaskularisasi plasenta, (4) teori adaptasi kardiovaskular, (5) teori inflamasi, (6) teori defisiensi gizi, dan (7) teori genetik (Angsar., 2008).

Menjawab beberapa teori di atas, ekstrak buah delima merah mampu meningkatkan kadar SOD dikarenakan pada buah delima merah kaya akan antioksidan. Buah delima merah (sekitar 50\% dari total berat delima) terdiri dari $80 \%$ jus dan $20 \%$ biji. Pada jusnya itu sendiri terdapat $85 \%$ air, $10 \%$ gula dan $1,5 \%$ pectin, asam askorbat serta polifenol flavonoid. (de Nigris et al., 2006). Fawole et al., (2011) meyampaikan, kandungan antosianin di dalam buah delima merah mencapai 16,5 - 26,9 per 100 gram jusnya. Antosianinlah yang bertanggungjawab atas pewarnaan pada buah delima merah.

Hal tersebut sesuai dengan teori yang menyatakan bahwa pada keadaan patologik 
akibat terbentuknya radikal bebas dalam jumlah berlebihan menyebabkan kerusakan sel endotel pada Pre eklampsi. Enzim-enzim yang berfungsi sebagai antioksidan endogen dapat menurun kadarnya. Oleh karena itu, jika terjadi peningkatan radikal bebas dalam tubuh (Preeklampsi), diperlukan antioksidan eksogen (buah delima merah) untuk mengeliminir dan menetralisir efek radikal bebas (Astuti et al., 2008).

\section{KESIMPULAN}

Terjadi penurunan kadar SOD A pada kultur HUVECs yang dipapar plasma preeklampsi dan ekstrak buah delima merah terbukti dapat meningkatkan kadar SOD pada kultur HUVECs yang dipapar plasma preeklampsi.

\section{DAFTAR PUSTAKA}

Angsar, M.D. 2008. Hipertensi dalam Kehamilan. Dalam: Saifuddin, A.B., Rachimhadhi, T., Winknjosastro, G.H., editors. IImu Kebidanan Sarwono Prawirohardjo. Edisi ke-4. Jakarta: PT Bina Pustaka Sarwono Prawirohardjo, 532-535.

Astuti, S., 2008, Ulasan Ilmiah: Isoflavon Kedelai dan Potensinya sebagai Penangkal Radikal Bebas, Jurnal Teknologi Industri dan Hasil Pertanian, 13 (2):126 - 136.

de Nigris F., Botti C., Williams-Ignarro S., Sica V., Ignarro L. J., Napoli C., 2006, Pomegranate juice reduces oxidized low-density lipoprotein downregulation of endhotelial notric oxide synthase in human coronary endothelial cells, Nitric Oxide 15, 259-263.
El-Bahr S.M., 2013, Biochemistry of free radicals and oxidative stress, Science Inernational 1 (5); 111 - 117.

Fawole, O. A., opara, U. L., Theron, K. L., 2011, 2011. Chemical and hytochemical properties and antioxidant activities of three pomegranate cultivars grown in south Africa, Food Bioprocess Tech, 85 : 202-206.

Fukai, T., and Ushio-Fukai M., 2011. Superoksida Dismutases: Role in Redox Signaling, Vascular Function, and Diseases, Antioxid Redox Signal. 15 (6):1583-1606.

Gupta S., Aziz N., Sekhon L., Agarwal R., Mansour G., Li J., Agarwal A., 2009, Lipid Peroxidation and Antioxidant Status in Preeclampsia, A Systematic Review. Obstetrical and Gynecological Survey, 64(11):750759.

Habli M., Sibai B.M., 2008, Hypertensive Disorders of Pregnancy, In: Danforth's obstetrics and gynecology. 10th ed. Philadelphia: Lippincott Williams \& Wilkins, 258266.

Harborne. 2005. Encyclopedia of Food and Color Additives. CRC Press, Inc. New York, 317-323.

Kholifa M., 2010, Pengaruh Konsentrasi Ekstrak Etanol Buah delima merah (Punica granatum L inn.) terhadap Peningkatan Apoptosis Sel Kanker Lidah Manusia Sp-C1 In Vitro, Biomedika, 2 (2).

Perry J.J.P., Shin D.S., Getzoff E.D., Tainer J.A., 2010, The structural biochemistry of the Superoksida dismutases, Biochim Biophys Acta, 1804(2): 245-262.

Roberts J.M., Hubel C.A., 2004, Oxidative Stress in Preeclampsia, American Journal of Obstetrics and Gynecology, 190:1177- 8. 
Rodrigo R., Parra M., Bosco C., Fernandez V., Barja P., Guajardo J., Mssina R., 2009. Pathophysiological basis for the prophylaxis of preeclampsia through early supplementation with antioxidant vitamins, University of Chile

World Health Organization, 2002, Global program to Conquer Preeclampsia / Eclampsia, available from: http://www.preeclampsia.org/statistic s.asp 